\title{
In vitro Propagation and Assessment of Genetic Relationships of Citrus Rootstocks Using ISSR Molecular Markers
}

\section{Constantinos SALIS ${ }^{1}$, Ioannis E. PAPADAKIS ${ }^{1}$, Spyridon KINTZIOS ${ }^{2}$, Marianna HAGIDIMITRIOU ${ }^{2 *}$}

\author{
${ }^{1}$ Agricultural University of Athens, Department of Crop Science, Iera Odos 75, 11855 Athens, \\ Greece; saliskonstantinos@yahoo.com; papadakis@aua.gr \\ ${ }^{2}$ Agricultural University of Athens, Department of Biotechnology, Iera Odos 75, 11855 Athens, \\ Greece; skin@aua.gr; marianna@aua.gr(*correspondingauthor)
}

\begin{abstract}
The behavior of six citrus rootstocks, Volkameriana, Citrumelo 'Swingle', Citrange 'Carrizo', Poncirus trifoliata 'Serra', Poncirus trifoliata 'Rubidoux' and Poncirus trifoliata 'Flying Dragon', in in vitro propagation was studied and compared for shoot proliferation and rooting. In addition, the genetic relationships among the rootstocks studied and other Citrus species, using the Inter-Simple Sequence Repeats (ISSR) molecular markers, were investigated. Nodal explants of three months old shoots were used in Murashige and Skoog medium supplemented with N6-benzyladenine (BA) for shoot proliferation and with naphthaleneacetic acid (NAA) for rooting. The rootstock Volkameriana showed a statistically significant higher number of shoots (1.81), shoot length $(15.14 \mathrm{~mm})$ and number of leaves per explant (5.81), while all three Poncirus trifoliata rootstocks showed the lowest numbers. The number of roots and root length per explant were evaluated at the end of the rooting phase. The rootstock 'Swingle' showed a higher number of roots per explant (4.2) followed by 'Flying Dragon' (3.93) and 'Carrizo' (3.23) rootstocks. The rootstocks 'Swingle' $(140.8 \mathrm{~mm})$, Volkameriana $(148 \mathrm{~mm})$ and 'Flying Dragon' (131.12 mm) had significantly higher root length per explant compared to 'Carrizo' (31 mm) and 'Rubidoux' (34.5 mm). The ISSR molecular marker technique used in the present study grouped successfully the different species, varieties and rootstocks studied, revealing their genetic variability. The genetic variability observed among the rootstocks ranged between 0.29 (Poncirus trifoliata 'Serra' and Citrumelo 'Swingle') and 0.60 (Volkameriana and Citrumelo 'Swingle'). The response of the rootstocks studied in in vitro propagation however is not related to their genetic affinity.
\end{abstract}

Keywords: citrus, in vitro, ISSR, micropropagation, molecular markers, PCR, rootstocks

\section{Introduction}

The genus Citrus belongs to the Rutaceae family, subfamily Aurantioideae, tribe Citrae and sub-tribe Citrinae (Reuther et al., 1967). Currently, there are two main classification systems of the Citrus genus, the W. T. Swingle system and the T. Tanaka system. According to Swingle (1943), the citrus genus is classified in two sub-genera the Citrus or Eucitrus sub-genus and the Papeda sub-genus. As centre of origin for the Citrus genus is considered the South-East Asia, and mostly the area between China and India (Gmitter and Hu, 1990; Soost and Roose, 1996).
The genus Citrus is cultivated in more than 100 countries, mostly in tropical and sub-tropical areas, and it represents one of the most important commercial fruit crops in terms of economic value and human nutrition. According to FAO (2015) in the year 2013/14 121,273.2 thousand tons of citrus were produced globally, of which 15,022.9 thousand tons were used as exportable products. China ranked first in citrus products, reaching 29,567 thousand tons $(2013 / 14)$, while countries of the Mediterranean region were the largest exporters with 12,282 thousand tons for the same year. The rootstock plays an important role in a productive orchard, since it affects the characteristics of the scion, such as growth, plant and fruit shape, fruit colour and weight, content of phytochemicals in fruits and juices, post-harvest storability (Ritenour et al., 2004; Rouphael et al., 2010; Orazem et al., 
384

2011; Turhan et al., 2011; Castle et al., 2016; Papadakis, 2016). In addition, rootstock helps the rootstock-scion combination to adapt to different abiotic factors, such as drought, flooding, salinity, mineral deficiency and toxicity, metal toxicity, heat, cold, soil temperature and oxygen, $\mathrm{pH}$ etc. (Papadakis et al., 2004; Colla et al., 2010; Hartmann et al., 2013; Savvas et al., 2010; Ghrab et al., 2014; Castle et al., 2016) and different biotic factors such as fungal and bacterial pathogens, virus, diseases, insects or nematodes (Mudge et al., 2009; Shokrollah et al., 2009; Roistacher et al., 2010; Louws et al., 2010; Castle et al., 2016). The choice of rootstock depends on its durability to enemies and diseases. Also, rootstocks affect the development of the graft, therefore the time of entering in production (Vasilakakis and Therios, 2006). Reduction of tree size without affecting production or plant health is a desirable characteristic (Soost and Roose, 1996). Citrus are considered sensitive to salinity, though some species show same tolerance to salt concentration (Storey and Walker, 1999; Ben-Hayyim and Moore, 2007). Rootstock's benefits except salinity resistance, are higher-yield and better growth, higher photosynthesis, water content and elevated concentrations of antioxidants and abscisic acid and lower contents of sodium or chloride, compared to ungrafted plants (Colla et al., 2010; Penella et al., 2016).

The propagation of Citrus rootstocks is commonly based on nucellar seeds (Barlass and Skene, 1982). This way of multiplication, though, has its limitation regarding the nucellar polyembryony, levels of heterozygosity, serious pathogen infections etc. Plant tissue culture approach solves the above problems by ensuring mass availability at plant material, maintaining clonal uniformity under given environmental conditions and preserving their selected traits (Hartmann et al., 2004). Furthermore, in vitro propagation systems can guarantee the production of pathogen-free material.

The morphogenic responses of Citrus cultured in vitro are depending on the genotype, explant type and culture medium (Carimi and De Pasquale, 2003; Perez-Tornero et al., 2010). In Citrus, the formation of adventitious organogenesis of shoots and buds has been observed (Barlass and Skene, 1982; Gmitter et al., 1992). This procedure is controlled by hormones, as the presence of BA cytokinin is decisive for the existence of organogenesis, but the ideal concentration depends on the genotype of the plant (Barlass and Skene, 1982).

The identification of species and varieties, as well as their genetic relationships, is possible with the aid of various markers like morphological, biochemical, cytogenetic, but the most efficient are the molecular (DNA) markers, which are based on the differences in their DNA sequence (Bretting and Widrlechner, 1995). In Citrus, markers that use PCR (Polymerase Chain Reaction) technology, have successfully been used, such as ISSR (Scarano et al., 2002), RAPD (Asadi and Isshiki, 2003), RFLP (Fang et al., 1997) and SCAR (Nicolosi et al., 2000).

The present study aimed to investigate the response to in vitro propagation (proliferation and rooting) of six Citrus rootstocks: 1. Volkameriana, used for its tolerance to tristeza virus and soil calcium, and give to the grafted variety early entering in production, 2. Citrumelo 'Swingle', used for its resistance to Phytophthora spp., nematodes, and tolerance to low temperatures (Gmitter et al., 2009; Vasilakakis and Therios, 2006), 3. Citrange 'Carrizo', used for its tolerance to tristeza virus and Phytophthora spp, and giving to the grafted variety high production and large size fruits with good quality, and three rootstocks coming from Poncirus trifoliate, used for their resistance to tristeza virus (Mestre $e t$ al., 1997), their resistance to low temperatures and their resistance to nematodes and Phytophthora spp, 4. Poncirus trifoliata 'Serra', 5. Poncirus trifoliata 'Rubidoux' and 6. Poncirus trifoliata 'Flying Dragon', with the later giving dwarf tree characteristics. In addition, the genetic relationships of the rootstocks studied, in combination with other Citrus species, have been investigated using the InterSimple Sequence Repeats (ISSR) molecular marker technique in order to reveal possible associations of the genotypes to in vitro response.

\section{Materials and Methods}

\section{Plant material}

Shoots of 3-year-old mother plants of three widely used rootstocks Volkameriana, Citrumelo 'Swingle', Citrange 'Carrizo' and three rootstocks used at a lesser extent, Poncirus trifoliata 'Serra', Poncirus trifoliata 'Rubidoux' and Poncirus trifoliata 'Flying Dragon', cultivated at the farms of 'Hellenic Plants' nursery (Xylokastro, Greece, $38.0773^{\circ} \mathrm{N}$, $22.6327^{\circ} \mathrm{E}$ ) were collected and used as plant material for the present study. Fifteen more samples from different Citrus species and varieties were also obtained from the same nursery. The biological material (Table 1) was originally acquired from CRSFA (Italy), the Pomology Institute of Poros (Greece) and the Agricultural University of Athens orchard.

\section{Micropropagation}

The collected shoots were defoliated and cut into node explants with a single node each of 1 to $3 \mathrm{~cm}$ in length. The following protocol for decontamination was used: the explants were washed out with a solution of commercial bleach $20 \%$ for $7 \mathrm{~min}$, followed by two $5 \mathrm{~min}$ washes with sterilized water, a solution of ethanol $70 \%$ for $1 \mathrm{~min}$ and finally, three washings with sterilized water.

The basal medium used was MS medium (Murashige and Skoog, 1962), supplemented with $30 \mathrm{~g} \mathrm{~L}^{-1}$ sucrose and 6 $\mathrm{g} \mathrm{L}^{-1}$ agar. For the proliferation phase the MS medium was supplemented with five different concentrations of N6Benzyladenine (BA) $(0,0.5,1,2$ and $4 \mathrm{ppm})$. For rooting stage, explants were transferred under aseptic conditions to $\mathrm{MS}$ medium supplemented with $30 \mathrm{~g} \mathrm{~L}^{-1}$ sucrose, $6 \mathrm{~g} \mathrm{~L}^{-1}$ agar and five different concentrations of naphthaleneacetic acid (NAA) $(0,0.5,1,2$ and $4 \mathrm{ppm})$. After the addition of growth regulators and adjustment of $\mathrm{pH}$ medium to 5.7$5.8,10 \mathrm{ml}$ of medium was dispensed into $150 \times 20 \mathrm{~mm}$ culture tubes. The culture tubes with medium were sterilized in autoclave at $121^{\circ} \mathrm{C}$ for $21 \mathrm{~min}$. Cultures were grown at $24 \pm 1{ }^{\circ} \mathrm{C}$, with a $16 \mathrm{~h}$ photoperiod. Proliferation responses were evaluated after 60 days and rooting responses after 70 days in culture. 


\section{DNA markers}

DNA from young healthy leaves from the rootstocks studied and from different Citrus species and varieties was extracted using the PowerPlant kit. Concentration and purity of the DNA was measured at 260 and $280 \mathrm{~nm}$ with a spectrophotometer (Unicam Helios $\gamma$ ). Five ISSR primers (UBC 807, UBC 810, UBC 812, UBC 817 and UBC818) were used for the study. DNA quality was also checked with electrograph of Agarose gel $1 \%(\mathrm{w} / \mathrm{v})$. The final concentrations for the PCR reaction were: 35 ng DNA, $2.0 \mathrm{mM} \mathrm{MgCl}_{2}, 200 \mathrm{mM}$ dNTPs, 1.0 Unit Taq and $0.5 \mathrm{mM}$ primer (Tripolitsiotis et al., 2013).

\section{DATA analysis}

Micropropagation data were analysed using analysis of variance (ANOVA) and the 'PASW Statistics 18' statistical package (SPSS Inc., Chicago, USA). For rooting phase, means of control ( 0 ppm NAA) and NAA-treated (2 ppm NAA) explants of each genotype were compared using Student's $t$-test, at a significance level of $\mathrm{p} \leq 0.05$. Genotype effects on proliferation and rooting stages, regardless of auxin (NAA) or cytokinin (BA) levels, respectively, were evaluated using the Duncan's multiple range test $(\mathrm{p} \leq 0.05)$. The same test was applied for the comparison of the effects of various BA concentrations in different proliferation traits of each genotype. The genetic similarities, obtained from the use of molecular markers, were calculated using the Jaccard algorithm and the dendrogram was constructed using the UPGMA (unweighted pair group method with arithmetic means).

\section{Results and Discussion}

\section{Proliferation phase}

Cytokinins and auxins are the most important plant growth regulators for shoot proliferation and rooting, respectively, in Citrus rootstocks explants (El-Morsy and Millet, 1996; Harada and Murai, 1996; Ghorbel et al., 1998; Murkute et al., 2008). In many species, BA has been found to be more effective than other cytokinins (like Kinetin) in inducing shoot development (Pattnaik et al., 1996; Yadav et al., 1990). BA has been the most commonly used plant growth regulator for proliferation of Citrus shoots (Carimi and De Pasquale, 2003). In the present study, the presence of $\mathrm{BA}$ increased the proliferation percentage in all rootstocks studied, except Volkameriana, which presented $100 \%$ shoot induction also in the control explants (0 ppm) (Table 2). Highest proliferation percentage for most of the rootstocks was observed at a concentration of 2 ppm BA. Tallón et al. (2012), reported also in Citrus rootstocks 'Alemow' and 'Cleopatra' the highest shoot proliferation using 2 ppm of BA. Rootstocks Citrange 'Carrizo' and Volkameriana also presented 100\% shoot induction in $1 \mathrm{ppm}$ of BA (Table 2). Many studies (Marques et al., 2011; Sharma et al., 2009; Pena et al., 1995; Rani et al., 2004) reported in various Citrus species highest proliferation percentage in that $1 \mathrm{ppm}$ of BA. Also, it was observed that by increasing the BA concentration from 2 to $4 \mathrm{ppm}$, proliferation percentage was decreased in most of the rootstocks studied. This observation comes in agreement with several researchers (El-Morsy and Millet, 1996; Normah et al., 1997; Al Bahrany, 2002) stating that higher concentrations of $\mathrm{BA}$ reduced shoot induction.

The presence of BA significantly increased the number of shoots per explant in Volkameriana, Citrange 'Carrizo' and Poncirus trifoliata 'Serra'. Maximum number of shoots per explant was observed in Volkameriana at $1 \mathrm{ppm}$ of BA (Table 2). Different researchers (Begum et al., 2008; Marques et al., 2011) observed in Citrus aurantium (sour orange) that $1 \mathrm{ppm}$ of $\mathrm{BA}$ is the optimum concentration for maximum number of shoots per explant. Citrange 'Carrizo'

Table 1. Rootstocks and varieties used in the present study, place of origin, and species

\begin{tabular}{|c|c|c|c|}
\hline No & Samples & Place of origin & Species/origin \\
\hline 2 & 'Rubidoux' & CRSFA (Italy) & P. trifoliata \\
\hline 3 & Siamelo & CRSFA & C. reticulata $\times$ C. sinensis $\times$ C. paradisi \\
\hline 4 & 'Flying Dragon' & CRSFA & P. trifoliata \\
\hline 5 & 'Serra' & CRSFA & P. trifoliata \\
\hline 7 & C. aurantium & CRSFA & C. aurantium \\
\hline 20 & Alemow & CRSFA & C.limon \\
\hline 13 & 'Citrumelo 4475’ & Pomology Institute of Poros (Greece) & P. trifoliata $\times C$. paradisi \\
\hline 15 & C. l. 'Eyreka' & CRSFA & C. limon \\
\hline 17 & C.1. 'Meyer' & CRSFA & C.limon \\
\hline 21 & C. s. 'Navellate' & CRSFA & C. sinensis \\
\hline 19 & C. s. 'Tarocco Rosso' & CRSFA & C. sinensis \\
\hline 9 & C. p. 'Marsh Seedless' & CRSFA & C.paradisi \\
\hline 22 & P. trifoliata & & P. trifoliata \\
\hline 23 & 'Swingle' & CRSFA & P. trifoliata $\times$ C.paradisi \\
\hline 27 & 'Citrumelo 1452’ & CRSFA & P. trifoliata $\times$ C. paradisi \\
\hline 24 & Volkameriana & CRSFA & C. medicax C. limon \\
\hline 6 & Cleopatra & CRSFA & C. reticulata \\
\hline 28 & 'Troyer' & CRSFA & P. trifoliata $\times$ C. sinensis \\
\hline 29 & ‘Carrizo’ & Pomology Institute of Poros & P. trifoliata $\times$ C. sinensis \\
\hline
\end{tabular}


Table 2. Shoot proliferation percentage, number of shoots per explant, total length of shoots per explant and number of leaves per explant as affected by genotype and BA concentration $(0,0.5,1,2$ or $4 \mathrm{ppm})$ in culture medium

\begin{tabular}{|c|c|c|c|c|c|}
\hline Genotypes & $\begin{array}{l}\text { Cytokinin } \\
\text { (BA, ppm) }\end{array}$ & $\begin{array}{c}\text { Shoot proliferation } \\
\text { percentage }(\%)\end{array}$ & $\begin{array}{c}\text { Number of shoots per } \\
\text { explant }\end{array}$ & $\begin{array}{l}\text { Total shoot length per } \\
\text { explant }(\mathrm{mm})\end{array}$ & $\begin{array}{c}\text { Number of leaves per } \\
\text { explant }\end{array}$ \\
\hline \multirow{5}{*}{ 'Carrizo' } & Control (0) & 47.20 & $0.72 \mathrm{a}$ & $6.29 \mathrm{a}$ & $2.21 \mathrm{a}$ \\
\hline & 0,5 & 73.45 & $1.05 \mathrm{~b}$ & $8.67 \mathrm{abc}$ & $3.70 \mathrm{bc}$ \\
\hline & 1 & 100.00 & $1.18 \mathrm{~b}$ & $9.79 \mathrm{bc}$ & $4.91 \mathrm{~d}$ \\
\hline & 2 & 100.00 & $1.20 \mathrm{~b}$ & $10.40 \mathrm{c}$ & $4.44 \mathrm{~cd}$ \\
\hline & 4 & 100.00 & $1.09 \mathrm{~b}$ & $7.45 \mathrm{ab}$ & $3.50 \mathrm{~b}$ \\
\hline \multirow{5}{*}{ Volkameriana } & Control (0) & 100.00 & $1.30 \mathrm{a}$ & $12.00 \mathrm{a}$ & $3.85 \mathrm{a}$ \\
\hline & 0,5 & 100.00 & $1.89 \mathrm{~b}$ & $19.52 \mathrm{~b}$ & $6.10 \mathrm{bc}$ \\
\hline & 1 & 89.39 & $2.11 \mathrm{~b}$ & $18.83 \mathrm{~b}$ & $7.22 \mathrm{c}$ \\
\hline & 2 & 100.00 & $2.05 \mathrm{~b}$ & $14.61 \mathrm{ab}$ & $7.16 \mathrm{c}$ \\
\hline & 4 & 81.67 & $1.75 \mathrm{~b}$ & $10.31 \mathrm{a}$ & $4.75 \mathrm{ab}$ \\
\hline \multirow{5}{*}{ 'Swingle' } & Control (0) & 21.12 & $1.00 \mathrm{a}$ & $8.33 \mathrm{ab}$ & $2.00 \mathrm{a}$ \\
\hline & 0,5 & 92.03 & $1.00 \mathrm{a}$ & $5.66 \mathrm{a}$ & $3.08 \mathrm{a}$ \\
\hline & 1 & 65.00 & $1.14 \mathrm{a}$ & $8.28 \mathrm{ab}$ & $4.14 \mathrm{a}$ \\
\hline & 2 & 100.00 & $1.00 \mathrm{a}$ & $10.83 \mathrm{ab}$ & $2.16 \mathrm{a}$ \\
\hline & 4 & 100.00 & $1.12 \mathrm{a}$ & $13.25 \mathrm{~b}$ & $3.37 \mathrm{a}$ \\
\hline \multirow{5}{*}{ 'Flying Dragon' } & Control (0) & 60.74 & $0.60 \mathrm{a}$ & $4.10 \mathrm{a}$ & $2.60 \mathrm{a}$ \\
\hline & 0,5 & 100.00 & $1.00 \mathrm{a}$ & $6.40 \mathrm{a}$ & $5.10 \mathrm{ab}$ \\
\hline & 1 & 100.00 & $1.07 \mathrm{a}$ & $6.14 \mathrm{a}$ & $6.00 \mathrm{~b}$ \\
\hline & 2 & 60.40 & $0.60 \mathrm{a}$ & $2.60 \mathrm{a}$ & $3.60 \mathrm{ab}$ \\
\hline & 4 & 40.67 & $0.63 \mathrm{a}$ & $3.27 \mathrm{a}$ & $3.00 \mathrm{a}$ \\
\hline \multirow{5}{*}{ 'Serra' } & Control (0) & 12.50 & $0.11 \mathrm{a}$ & $0.88 \mathrm{a}$ & $0.41 \mathrm{a}$ \\
\hline & 0,5 & 43.70 & $0.43 \mathrm{ab}$ & $2.62 \mathrm{ab}$ & $1.81 \mathrm{ab}$ \\
\hline & 1 & 64.20 & $0.64 b c$ & $4.21 \mathrm{bc}$ & $2.78 \mathrm{bc}$ \\
\hline & 2 & 81.20 & $0.93 c$ & $6.00 c$ & $3.75 \mathrm{c}$ \\
\hline & 4 & 66.60 & $0.66 b c$ & $2.80 \mathrm{ab}$ & $2.86 \mathrm{bc}$ \\
\hline \multirow{5}{*}{ 'Rubidoux' } & Control (0) & 6.34 & $1.00 \mathrm{a}$ & $15.00 \mathrm{~b}$ & $1.00 \mathrm{a}$ \\
\hline & 0,5 & 46.30 & $1.16 \mathrm{a}$ & $6.33 \mathrm{a}$ & $4.50 \mathrm{bc}$ \\
\hline & 1 & 63.00 & $1.00 \mathrm{a}$ & $5.45 \mathrm{a}$ & $5.36 \mathrm{c}$ \\
\hline & 2 & 60.75 & $0.90 \mathrm{a}$ & $8.90 \mathrm{a}$ & $3.20 \mathrm{bc}$ \\
\hline & 4 & 52.63 & $0.75 a$ & $4.81 \mathrm{a}$ & $2.31 \mathrm{ab}$ \\
\hline
\end{tabular}

Different letters in the same column and within each genotype indicate significant differences at $\mathrm{P}<0.05$ (Duncan's multiple range test)

and Poncirus trifoliata 'Serra' showed highest number of shoots per explant at 2ppm of BA (Table 2). Perez-Tornero et al. (2010) in Citrus limon varieties 'Fino 49', 'Fino 77' and 'Messina', and Tallón et al. (2012) in Cleopatra rootstock, also stated that maximum number of shoots per explant were obtained at $2 \mathrm{ppm}$ of BA. On the other hand, Kitto and Young (1981), noted that in 'Carrizo' highest number of shoots per explant was obtained using higher cytokinin concentrations, like $5 \mathrm{ppm}$ of BA. Shoot length was not significantly affected by the presence of BA in all rootstocks studied, except Volkameriana, in which significant differences were shown among the different concentrations of BA, and 'Rubidoux', in which the presence of BA significantly decreased shoot length. Tallón et al. (2012), observed that the presence of BA did not affect significantly the shoot length in sour orange, but significantly affected the shoot length in Alemow and Cleopatra rootstocks. Perez-Tornero et al. (2010), in various lemon varieties, and Savita Singh et al. (2011) in Citrus jambhiri 'Lush', noted that BA presence significantly increased shoot length. In the present study, total shoot length per explant was significantly increased in Volkameriana, 'Carrizo' and
'Serra', in the presence of BA, but did not significantly affect the total shoot length per explant of Citrumelo 'Swingle' and Poncirus trifoliata 'Flying Dragon' (Table 2).

\section{Rootingphase}

The kind and the concentration of the auxin used in the culture media, play a key role in in vitro rooting and is affected by the plant species and the variety (George, 1996). The presence of auxin, including NAA or IBA, in the culture media is generally necessary to promote rooting in Citrus in vitro cultures (Carimi and De Pasquale, 2003). The most effective auxins for rooting are NAA, IBA and IAA (Bhojwani and Razdan, 1996). Rooting in some varieties is favored by a medium containing more than one hormone, like Citrus reticulata 'Blanco' and Citrus limon Burm. f. (Singh et al., 1994), while in others NAA alone induces rooting, like Poncirus trifoliata L. (Starrantino and Russo, 1980). In the present study, the presence of NAA in the culture media increased the rooting percentage in all rootstocks studied. In most of the rootstocks, maximum rooting percentage was obtained in the presence of $2 \mathrm{ppm}$ NAA (Table 3). This finding is in agreement with different 
researchers (Edriss and Burger, 1984; Tallón et al., 2012; Gill $e t$ al., 1995), stating that, in various Citrus species, 2 ppm of NAA was the optimum concentration for maximum rooting percentage. In addition, other studies have shown that maximum rooting, in various Citrus species, can be obtained in lower NAA concentrations, such as 1 ppm (Kitto and Young, 1981; Bordon et al., 2000; Al Bahrany, 2002; Rathore et al., 2007) or 0.5 ppm of NAA (Savita Singh et al., 2011). Rootstock Poncirus trifoliata 'Rubidoux' in control $(0 \mathrm{ppm})$ obtained $0 \%$ rooting in explants (Table 3). Similarly, Al Bahrany (2002) observed that Citrus aurantifolia had $0 \%$ rooting in the absence of NAA.

The presence of auxin significantly increased the number of roots per explant in all rootstocks studied, except Citrange 'Carrizo' and Volkameriana. Rootstocks Poncirus trifoliata 'Flying Dragon', Citrumelo 'Swingle' and Poncirus trifoliata 'Rubidoux' presented the highest number of roots per explant using $2 \mathrm{ppm}$ of NAA (Table 3), Volkameriana with $1 \mathrm{ppm}$ of NAA and Citrange 'Carrizo' with $4 \mathrm{ppm}$ of NAA (data not shown). Al Bahrany (2002) observed that the number of roots per explant in Citrus aurantifolia 'Swing' is increased with the simultaneous increase of NAA in the media, and $2 \mathrm{ppm}$ of NAA was the optimum concentration for maximum number of roots per explant. Tallón et al. (2012), also observed in Sour Orange that maximum roots per explant were obtained with $2 \mathrm{ppm}$ of NAA. Furthermore, in Cleopatra (Tallón et al., 2012), Citrus macrophylla (Ghorbel et al., 1998; Bordon et al., 2000) and Citrus reticulata 'Blanco' (Gill et al., 1995) 1 ppm of NAA was the optimum concentration of auxin for maximum number of roots per explants.

Total root length per explant was not significantly affected by the presence of NAA, in all rootstocks studied, except Poncirus trifoliata 'Rubidoux'.

\section{Genotype effect on proliferation and rooting phases}

One of the most important factors affecting the proliferation and rooting process of the explants is genotype. Genotype influences shoot formation and rooting (Cezar $e t$ al., 2015). Gomes et al. (2010) stated that the genotype of the donor plants is also a factor interfering with the multiplication. Also, Scaltsoyiannes et al. (1998), observed that in Juglans regia, genotype plays a crucial role in micropropagation.

Comparing the rootstocks studied, Volkameriana presented statistically significant higher number of shoots per explants (Fig. 1) as well as statistically significant higher total shoot length per explants (Fig. 2), followed by Citrange 'Carrizo' and Citrumelo 'Swingle'. This is in agreement with Carimi and De Pasquale (2003) who noted that the number of shoots per explants is different depending on genotype studied. The Poncirus trifoliata 'Serra' rootstock presented statistically significant lower number of shoots per explant and, along with Poncirus trifoliata 'Flying Dragon' and Poncirus trifoliata 'Rubidoux', statistically significant lower total shoot length per explant. Statistically significant higher root number per explant was obtained by Poncirus trifoliata 'Flying Dragon' and Citrumelo 'Swingle', followed by Citrange 'Carrizo' (Fig. 3). Volkameriana presented statistically significant lower number of roots per explant, along with Poncirus trifoliata 'Rubidoux'. Regarding the total root length per explants, statistically significant higher length was obtained from Volkameriana, Poncirus trifoliata 'Flying Dragon' and Citrumelo 'Swingle' rootstocks, while lower length was observed in Citrange 'Carrizo' and Poncirus trifoliata 'Rubidoux' (Fig. 4).

\section{Genetic variability of the rootstocks studied}

The use of molecular techniques has made taxonomic classification of Citrus species possible and more accurate. Knowledge of genetic variability and relationships among different genotypes is an important factor for the efficient exploitation of varieties' potential (Russell et al., 1997). Molecular markers differ in variability rates of detection and their efficiency depends on the species used (Lonn et al., 1995). The ISSR molecular markers technique used in the present study separated successfully 21 different samples belonging to different species, varieties and the rootstocks studied. Fang et al. (1997), used 46 ISSR molecular markers on various Citrus species, but only 11 of them were found to be polymorphic. Pasquale et al. (2006), used 11 ISSR and 6 RAPD molecular markers in order to test the genetic variability of five sour orange clones.

Table 3. Rooting percentage of the regenerated shoots, number of roots per explants, total root length per explants, drying rate and fresh weight of roots per length as affected by genotype and the concentration of NAA $(0$ or $2 \mathrm{ppm})$ in the culture medium

\begin{tabular}{|c|c|c|c|c|c|c|}
\hline Genotypes & $\begin{array}{c}\text { Auxin } \\
\text { (a-NAA, ppm) }\end{array}$ & $\begin{array}{c}\text { Rooting } \\
\text { percentage }(\%)\end{array}$ & $\begin{array}{c}\text { Number of roots } \\
\text { per explant }\end{array}$ & $\begin{array}{l}\text { Total root length } \\
\text { per explant }(\mathrm{mm})\end{array}$ & $\begin{array}{l}\text { Drying rate } \\
(\%)\end{array}$ & $\begin{array}{c}\text { Fresh weight of root per } \\
\text { length }(\mathrm{mg} / \mathrm{mm})\end{array}$ \\
\hline \multirow{2}{*}{ 'Carrizo' } & Control (0) & 31.20 & 2.60 & 156.40 & 00.00 & 0.012 \\
\hline & 2 & 72.13 & $3.62 \mathrm{~ns}$ & $142.25 \mathrm{~ns}$ & $12.00 \mathrm{~ns}$ & $0.023^{*}$ \\
\hline \multirow{2}{*}{ Volkameriana } & Control (0) & 23.70 & 1.25 & 33.00 & 75.00 & 0.025 \\
\hline & 2 & 73.65 & $1.64 \mathrm{~ns}$ & $30.00 \mathrm{~ns}$ & $57.00 \mathrm{~ns}$ & $0.021 \mathrm{~ns}$ \\
\hline \multirow{2}{*}{ 'Flying Dragon' } & Control (0) & 64.24 & 1.50 & 84.16 & 00.00 & 0.015 \\
\hline & 2 & 100.00 & $5.40^{*}$ & $159.30 \mathrm{~ns}$ & $30.00 \mathrm{~ns}$ & $0.019 \mathrm{~ns}$ \\
\hline \multirow{2}{*}{ 'Swingle' } & Control (0) & 50.80 & 2.00 & 129.00 & 00.00 & 0.012 \\
\hline & 2 & 100.00 & $5.66^{* *}$ & $148.00 \mathrm{~ns}$ & $57.00 \mathrm{~ns}$ & $0.018 \mathrm{~ns}$ \\
\hline \multirow{2}{*}{ 'Rubidoux' } & Control (0) & 00.00 & 0.00 & 0.00 & 00.00 & 0.00 \\
\hline & 2 & 22.45 & $1.50^{*}$ & $69.00^{* *}$ & $100.00^{* * *}$ & $0.015^{*}$ \\
\hline
\end{tabular}

Asterisks in parenthesis indicate significant differences between control and 2 ppm BA-treated plants of the same genotype, at $\mathrm{P}<0.05\left({ }^{*}\right), \mathrm{P}<0.010\left({ }^{* *}\right)$ or $\mathrm{P}<0.001\left({ }^{* * *}\right)$; n.s. indicates non-significant differences $(P>0.05)$ (Student's t-test) 
388

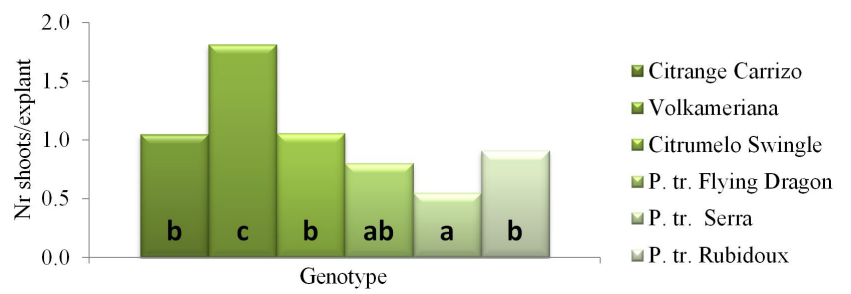

Fig. 1. Number of shoots per explant, of the genotypes tested in culture medium MS supplemented with different levels of BA. Different letters indicate significant differences among genotypes at $\mathrm{P}<0.05$ (Duncan's multiple range test)

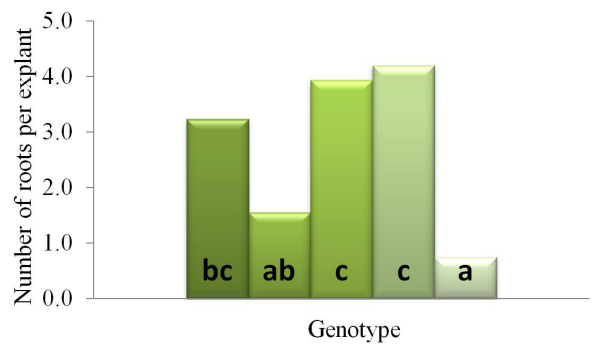

\author{
$\square$ Citrange Carrizo \\ $\square$ Volkameriana \\ $\square$ P. tr. Flying Dragon \\ $\square$ Citrumelo Swingle \\ $\triangle \mathrm{P}$. tr. Rubidoux
}

Fig. 3. Number or roots per explant, of the genotypes tested, in culture medium MS supplemented with different levels of NAA. Different letters indicate significant differences among genotypes at $\mathrm{P}<0.05$ (Duncan's multiple range test)

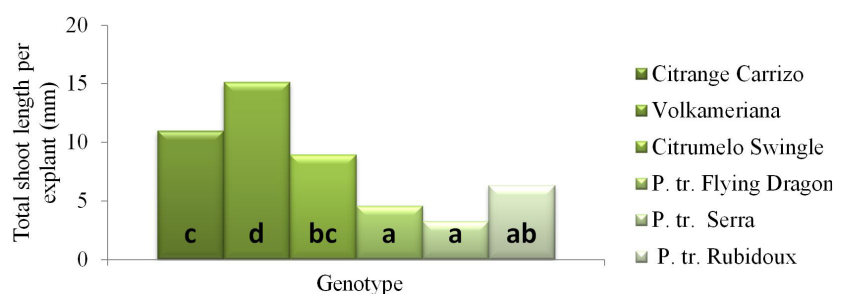

Fig. 2. Total shoot length per explant of the genotypes tested in culture medium MS supplemented with different levels of BA. Different letters indicate significant differences among genotypes at $\mathrm{P}<0.05$ (Duncan's multiple range test)

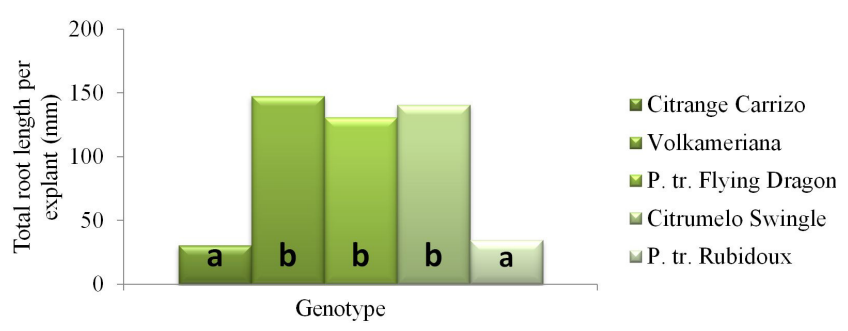

Fig. 4. Total length of roots per explant, of the genotypes tested, in culture medium supplemented with different levels of NAA. Different letters indicate significant differences among genotypes at $\mathrm{P}<0.05$ (Duncan's multiple range test)

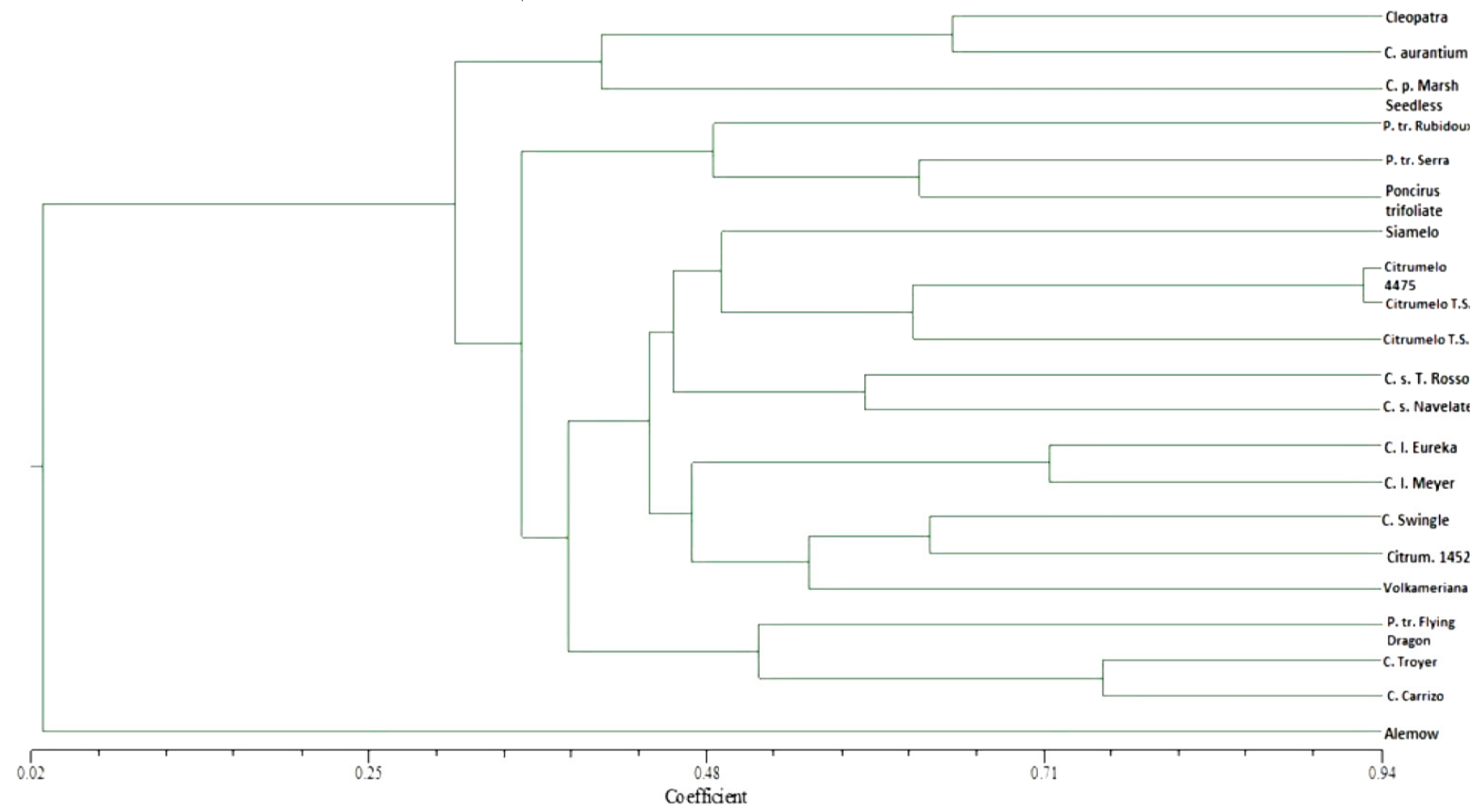

Fig. 5. UPGMA dendrogram for Citrus rootstocks and varieties based on five ISSR markers

According to the cluster (Fig. 5), among the rootstocks studied for their in vitro responses, higher genetic similarity was presented between Volkameriana and Citrumelo 'Swingle' (0.60), followed by Citrumelo 'Swingle' and Citrange 'Carrizo' (0.59). Amar et al. (2011), also observed a high genetic similarity (0.82) between Citrumelo and Citrange. Likewise, Romdhane et al. (2016), placed Citrange 'Carrizo' and Citrumelo 'Swingle' in a same genetic group. On the contrary, Poncirus trifoliata 'Serra' and Citrumelo 'Swingle' showed low genetic affinity, followed by Volkameriana and Poncirus trifoliata 'Serra' (0.32).

Poncirus trifoliata, Poncirus trifoliata 'Rubidoux' and Poncirus trifoliata 'Serra' were grouped together, with higher genetic similarity observed between Poncirus trifoliata and Poncirus trifoliata 'Serra' (0.63). The genotypes Citrange 'Carrizo' and Citrange 'Troyer' showed high genetic 
similarity (0.75) and were grouped together with Poncirus trifoliata 'Flying Dragon' in the dendrogram (Fig. 5). Several studies (Uzun et al., 2009; Tripolitsiotis et al., 2013) using ISSR, RAPD and SRAP markers, revealed that Citrange 'Carrizo' and Citrange 'Troyer' are very similar genetically. Citrumelo ' 4475 ' presented high genetic similarity (0.93) with one sample of Citrumelo ' 4475 ' which came from micropropagation and lower genetic similarity with the second sample of Citrumelo '4475' which came also from micropropagation (Fig. 5). It is possible that the first sample which came from micropropagation was taken from the same donor plant with the sample of Citrumelo ' 4475 ', while the second sample might have come from a different donor plant. Citrumelo 'Swingle' and Citrumelo '1452' were grouped together in another branch of the cluster. In addition, Romdhane et al. (2016), placed 'Swingle' in a group with 'Troyer' and Amar et al. (2011), observed high genetic similarity between Citrumelo and Citrange 'Citrange'. Volkameriana was grouped together with Citrus limon 'Eureka' and Citrus limon 'Meyer' and this was in agreement with the findings of Uzun et al. (2009). Similarly, Tripolitsiotis et al. (2013) observed that Volkameriana presents genetic similarities with various lemon varieties and several researchers (Golein et al., 2012; Hamza, 2013) place Volkameriana in the same genetic group with different varieties of Lime.

\section{Conclusions}

Genotype affected significantly the proliferation percentage, the number of shoots and the total shoot length per explant. The results of the in vitro proliferation stage indicated that, among the six rootstocks studied, Volkameriana had the higher number of new shoots, shoot length and number of leaves per explant, while all three Poncirus trifoliata rootstocks ('Serra', 'Rubidoux' and 'Flying Dragon') showed the lowest numbers. Genotype affected also significantly the rooting percentage, number of roots and total root length per explant. Among the rootstocks studied, Citrumelo 'Swingle', presented significantly higher number of roots and total root length per explant. The presence of $\mathrm{BA}$ increased the proliferation percentage in all the rootstock studied, except Volkameriana. Highest proliferation percentage was observed at $2 \mathrm{ppm}$ of $\mathrm{BA}$ for most of the rootstocks studied. BA presence significantly increased the number of shoots and the total shoot length per explant in Citrange 'Carrizo', Volkameriana and Poncirus trifoliata 'Serra' rootstocks. The presence of NAA increased the rooting percentage in all the rootstocks studied. In most rootstocks, maximum rooting was obtained at $2 \mathrm{ppm}$ of NAA. The presence of NAA increased the number of roots per explant in the rootstocks studied, except Citrange 'Carrizo'. On the other hand, NAA presence did not affect significantly the total root length per explant in any of the rootstocks studied, except Citrange 'Carrizo'. The study of the genetic relationships showed that the rootstocks studied presented a broad genetic base with great genetic variability but response to in vitro propagation is not related to their genetic affinity.

\section{References}

Al Bahrany AM (2002) Effect of phytohormones on in vitro shoot multiplication and rooting of lime Citrus aurantifolia (Christm.) Swing. Scientia Horticulturae 95:285-295.

Amar MH, Biswas MK, Zhang Z, Guo WW (2011). Exploitation of SSR, SRAP and CAPS-SNP markers for genetic diversity of Citrus germplasm collection. Scientia Horticulturae 128(3):220-227.

Asadi AA, Isshiki S (2003). Molecular characterization and genetic diversity among Japanese acid Citrus (Citrus spp.) based on RAPD markers. Journal of Horticultural Science and Biotechnology 78(1)108-112.

Barlass M, Skene KGM (1982). In vitro plantlet formation from Citrus species and hybrids. Scientia Horticulturae 17(4):333-341.

Begum Y, Roy S, Bandyopadhyay S, Dasgupta SBU, Chakraborty A, Raychaudhuri SS (2008). Radiation induced alterations in Vigna radiata during in vitro somatic embryogenesis. International Journal of Radiation Biology 84(2):165-175.

Ben-Hayyim G, Moore GA (2007). Recent advances in breeding Citrus for drought and saline stress tolerance. In: Jenks MA (Ed). Advances in molecular breeding toward drought and salt tolerant crops. Springer pp 627-642.

Bhojwani SS, RazdanMK (1996). Plant tissue culture: theory and practice a revised edition. Elsevier, Amsterdam, TheNetherlands.

Bordón Y, Guardiola JL, García-Luis A (2000). Genotype affects the morphogenic response in vitro of epicotyl segments of Citrus rootstocks. Annals of Botany 86(1):159-166.

Bretting PK, Widrlechner MP (1995). Genetic markers and plant genetic resource management. In: Janick J, Wiley J (Eds). Plant Breeding Reviews pp 11-86.

Carimi F, De Pasquale F (2003). Micropropagation of Citrus. In: Jain SM, Ishii K (Eds). Micropropagation of woody trees and fruits. Kluwer, The Netherlands pp 589-619.

Castle WS, Bowman KD, Grosser JW, Futch SH, Graham JH (2016). Florida Citrus rootstock selection guide (3rd Ed). UF/IFAS Extension Service, University of Florida.

Cézar TM, Higa AR, Koehler HS, Ribas LLF (2015). Influence of culture medium, explant length and genotype on micropropagation of Pinus taeda L. Ciência Florestal 25(1):13-22.

Colla G, Rouphael Y, Leonardi C, Bie Z (2010). Role of grafting in vegetable crops grown under saline conditions. Scientia Horticulturae 127(2):147-155.

Edriss MH, Burger DW (1984). In vitro propagation of 'Troyer' citrange from epicotyl segments. Scientia Horticulturae 23(2):159-162.

El-Morsy AA, Millet B (1996). Rhythmic growth and optimization of micropropagation: the effect of excision time and position of axillary buds on in vitro culture of Citrus aurantium L. Annals of Botany 78:197-202.

FAO (2015). Food and Agriculture Organization of the United Nations Citrus fruit statistics 2015. Retrieved March 212017 from www.fao.org/3/a-i5558e.pdf.

Fang DQ, Roose ML, Krueger RR, Federici CT (1997). Fingerprinting trifoliate orange germ plasm accessions with isoenzymes, RFLPs and 
390

inter-simple sequence repeat markers. Theoretical and Applied Genetics 95:211-219.

George EF (1996). Plant propagation by tissue culture. Part II. In practice. Exegetics Limited Edington.

Ghorbel R, Navarro L, Durán-Vila N (1998). Morphogenesis and regeneration of whole plants of grapefruit (Citrus paradisi); sour orange (C. aurantium) and alemow (C. macrophylla). Journal of Horticultural Science and Biotechnology 73:323-327.

Ghrab M, Mimoun MB, Masmoudi MM, Mechlia NB (2014). Chilling trends in a warm production area and their impact on flowering and fruiting of peach trees. Scientia Horticulturae 178:87-94.

Gill MIS, Singh Z, Dhillon BS, Gosal SS (1995). Somatic embryogenesis and plantlet regeneration in mandarin (Citrus reticulata Blanco).Scientia Horticulturae 63(3):167-174.

Gmitter FG Jr, Hu X (1990). The possible role of Yunnan, China in the origin of contemporary Citrus species (Rutaceae). Economic Botany 44:267-277.

Gmitter FG Jr, Grosser JW, Moore GA (1992). Citrus. In: Hammerschlag FA, Ritz RE (Eds). Biotechnology of Perennial Fruit Crops. CAB International, Wallingford, UKpp 335-369.

Gmitter FG Jr, Soneji JR, Nageswara Rao M (2009). Citrus Breeding. In: Jain SM, Priyadarshan PM (Eds). Breeding Plantation Tree Crops: TemperateSpecies, Springer Science and Business Media pp 105-134.

Golein B, Bigonah M, Azadvar M, Golmohammadi M (2012). Analysis of genetic relationship between 'Bakraee' (Citrus sp.) and some known Citrus genotypes through SSR and PCR-RFLP markers. Scientia Horticulturae 148:147-153.

Gomes, F, Simoes, M, Lopes ML, Canhoto JM (2010). Effect of plant growth regulators and genotype on the micropropagation of adult trees of Arbutus unedo L.(strawberry tree). New Biotechnology 27(6):882892.

Hamza EM (2013). Genetic diversity of some Citrus varieties based on microsatellite and RAPD molecular markers in Egypt. World Journal of Agricultural Sciences 9(4):316-324.

Harada H, Murai Y (1996) Clonal propagation of Poncirus trifoliata through culture of shoot primordia. Journal of Horticultural Science and Biotechnology 71:887-892.

Hartmann HT, Kester DE, Davies FTD, Geneve RL (2004). Plant propagation. Prentice Hall, New Delhi.

Hartmann HT, Kester DE, Davies FT, Geneve RL (2013). Hartmann and Kester's plant propagation: principles and practices. 8th Edn. Pearson Education Limited, Harlow.

Kitto SL, Young MJ (1981). In vitro propagation of Carrizo citrange. HortScience 16:305-306.

Louws FJ, Rivard CL, Kubota C (2010). Grafting fruiting vegetables to manage soilborne pathogens, foliar pathogens, arthropods and weeds. Scientia Horticulturae 127:127-146.

Lonn M, Prentice HC, TegelstrGm H (1995). Genetic differentiation in Hippocrepis emerus (Leguminosae): allozyme and DNA fingerprint variation in disjunct Scandinavian populations. Molecular Ecology 4:3948.

Marques NT, Nolasco GB, Leitão JP (2011). Factors affecting in vitro adventitious shoot formation on internode explants of Citrus aurantium L.cv. Brazilian. Scientia Horticulturae 129(2):176-182.

Mestre PF, Asins MJ, Pina JA, Carbonell EA, Navarro L (1997). Molecular markers flanking citrus tristeza virus resistance gene from Poncirus trifoliata (L.). Theoretical and Applied Genetics 94:458-464.

Mudge K, JanickJ, Scofield S, Goldschmidt EE (2009). A history of grafting. Horticultural Reviews 35:437-493.

Murashige T, Skoog F (1962). A revised medium for rapid growth and bioassays with tobacco tissue cultures. Physiologia Plantarum 15:473497.

Murkute AA, Sharma S, Singh SK (2008). Rapid clonal in vitro multiplication of Citrus jambhiri and Citrus karna. Indian Journal of Horticulture 65:127-133.

Nicolosi E, Deng ZN, Gentile A, La Malfa S, Continella G, Tribulato E (2000). Citrus phylogeny and genetic origin of important species as investigated by molecular markers. Theoretical and Applied Genetics 100:1155-1166.

Normah MN, Hamidah S, Ghani FD (1997). Micropropagation of Citrus halimii - an endangered species of South-east Asia. Plant Cell, Tissue and Organ Culture 50:225-227.

Orazem P, Stampar F, Hudina M (2011). Fruit quality of Redhaven and Royal Glory peach cultivars on seven different rootstocks. Journal of Agricultural and Food Chemistry 59:93949401.

Papadakis, IE, Dimassi KN, Bosabalidis AM, Therios IN, Patakas A (2004). Effects of $B$ excess on some physiological and anatomical parameters of 'Navelina' orange plants grafted on two rootstocks. Environmental and Experimental Botany 51:247-257.

Papadakis IE (2016). The timeless contribution of rootstocks towards successful horticultural farming: from ancient times to the climate change era. American Journal of Agricultural and Biological Sciences 11(4):137-141.

Pasquale DeF, Siragusa M, Abbate L, Tusa N, Pasquale DeC, Alonzo G (2006). Characterization of five sour orange clones through molecular markers and leaf essential oils analysis. Scientia Horticulturae 109(1):54 59.

Pattnaik SK, Sahoo Y, Chand PK (1996). Micropropagation of a fruit tree, Morus australis Poir. Syn. M. acidosa Griff. Plant Cell Reports 15:841845.

Peña L, Cervera M, Juárez J, Navarro A, Pina JA, Durán-Vila N, Navarro L (1995). Agrobacterium-mediated transformation of sweet orange and regeneration of transgenic plants. Plant Cell Reports 14(10):616-619.

Penella C, Landi M, Guidi L, Nebauer SG, Pellegrini E, San Bautista A, Calatayud A (2016). Salt-tolerant rootstock increases yield of pepper under salinity through maintenance of photosynthetic performance and sinks strength. Journal of Plant Physiology 193:1-11.

Pérez-Tornero O, Tallón, CI,Porras I (2010). An efficient protocol for micropropagation of lemon (Citrus limon) from mature nodal segments. Plant Cell, Tissue and Organ Culture 100(3):263-271.

Rani G, Singh B, SharmaS, Rehan L, Zaidi AA, Nagpal A, Virk GS (2004). Micropropagation of Kinnow (Citrus nobilis $\times$ Citrus deliciosa) through nodal segments. Journal of Indian Botanical Society 83:26-29.

Rathore JS, Rathore MS, Singh M, Singh RP, Shekhawat NS (2007). 
Micropropagation of mature tree of Citrus limon. Indian Journal of Biotechnology 6:239-244.

Reuther W, Batchelor LD, Webber HJ (1967). The Citrus industry. In: History, World Distribution, Botany and Varieties, Vol 1. University of California, Division of Agricultural Sciences, Library of Congress Catalog CardNo67-63041 USA.

Ritenour MA, Dou H, Bowman KD, Boman BJ, Stover E, Castle WS (2004). Effect of rootstock on stem-end rind breakdown and decay of fresh citrus. Hort Technology 14:315-319.

Roistacher CN, Graca JV, Muller GW (2010). Cross protection against Citrus tristeza virus - a review. Proceedings of the 17 th Conference of the International Organization of Citrus Virologists (OCV 10), Adana, Turkeypp 1-27.

Romdhane MB, Riahi L, Selmi A, Zoghlami N (2016). Patterns of genetic structure and evidence of gene flow among Tunisian Citrus species based on informative nSSR markers. Comptes Rendus Biologies 339(9):371377.

Rouphael Y, Schwarz D, Krumbein A, Colla G (2010). Impact of grafting on product quality of fruit vegetables. Scientia Horticulturae 127:172179.

Russell JR, FullerJD, Macaulay M, Hatz BG, Jahoor A, Powell W, Waugh R (1997). Direct comparison of levels of genetic variation among barley accessions detected by RFLPs, AFLPs, SSRs and RAPDs. Theoretical and Applied Genetics 95:714722.

Savita Singh B, Virk GS, Nagpal AK (2011). An efficient plant regeneration protocol from callus cultures of Citrus jambhiri Lush. Physiology and Molecular Biology of Plants 17(2):161-169.

Savvas D, Colla G, Rouphael Y, Schwarz D (2010). Amelioration of heavy metal and nutrient stress in fruit vegetables by grafting. Scientia Horticulturae 127:156-161.

Scaltsoyiannes A, Tsoulpha P, Panetsos KP, Moulalis D, (1998). Effect of genotype on micropropagation of walnut trees (Juglans regia).Silvae Genetica 46:326-331.

Scarano MT, Abbate L, Ferrante S, Lucretti S, Tusa N (2002). ISSR-PCR technique: a useful method for characterizing new allotetraploid somatic hybrids of mandarin. Plant Cell Reports 20:1162-1166.

Sharma S, Prakash A, Tele A (2009). In vitro propagation of Citrus rootstocks. Notulae Botanicae Horti Agrobotanici Cluj-Napoca 37(1):8488.
Shokrollah H, Abdullah TL, Sijam K, Abdullah SNA, Abdullah NAP (2009). Differential reaction of Citrus species in Malaysia to huanglongbing(HLB) disease using grafting method. American Journal of Agricultural and Biological Sciences 4(1):32-38.

Singh S, Ray BK, Bhattacharyya S, Deka PC (1994). In vitro propagation of Citrus reticulata Blanco and Citrus limon Burm.f. HortScience 29:214 216.

Soost RK, Roose ML (1996). Citrus. In: Janick J, Moore JN (Eds). Fruit Breeding, Vol I, Tree and Tropical Fruits. John Wiley and Sons Inc, New York, Chichester, Brisbane, Toronto, Singaporepp 257-323.

Starrantino A, Russo R (1980). Seedlings from undeveloped ovules of ripe fruits of polyembryonic Citrus cultivars. HortScience 15:296-297.

Storey R, Walker RR (1999). Citrus and salinity. Scientia Horticulturae 78:39-81.

Swingle WT (1943). The botany of Citrus and its wild relatives of the orange subfamily. In: Webber HJ, Batchelor LD (Eds). The Citrus Industry Vol 1.University ofCalifornia pp 129-474.

Tallón CI, Porras I, Pérez-Tornero O (2012). Efficient propagation and rooting of three Citrus rootstocks using different plant growth regulators. In Vitro Cellular \& Developmental Biology-Plant 48(5):488-499.

Tripolitsiotis C, Nikoloudakis N, Linos A, Hagidimitriou M (2013). Molecular characterization and analysis of the Greek Citrus germplasm.Notulae Botanicae Horti Agrobotanici Cluj-Napoca 41(2):463-471.

Turhan A, Ozmen N, Serbeci MS, Seniz V (2011). Effects of grafting on different rootstocks on tomato fruit yield and quality. Horticultural Science 38:142-149.

Uzun A, Yesiloglu T, Aka-Kacar Y, Tuzcu O, Gulsen O (2009). Genetic diversity and relationships within Citrus and related genera based on sequence related amplified polymorphism markers (SRAPs).Scientia Horticulturae 121(3):306-312.

Vasilakakis M, Therios I (2006). Citrus. In: Pomology Courses ( $\left.2^{\text {nd }} E d\right)$. Thessalonikipp 9-53.

Yadav U, Lal M, Jaiswal VS (1990). Micropropagation of Morus nigra L. from shoot tip and nodal explants of mature trees. Scientia Horticulturae 44:61-67. 